\title{
Aspects of Common Eider Nesting Ecology in Labrador
}

\author{
KEITH CHAULK, ${ }^{1}$ GREGORY J. ROBERTSON,${ }^{2}$ WILLIAM A. MONTEVECCHI ${ }^{3}$ and PIERRE C. RYAN ${ }^{2}$
}

\author{
(Received 27 January 2004; accepted in revised form 13 May 2004)
}

\begin{abstract}
The status, distribution, and nesting ecology of common eiders (Somateria mollissima) breeding in Labrador are not well known. This study is an initial effort to improve understanding of the nesting ecology of eiders on the Labrador coast, a zone of intergradation between the northern (S. m. borealis) and American (S. m. dresseri) subspecies of common eider. During 1998 and 1999, 187 islands were surveyed for nesting eiders at four sites (from north to south: Nain, Hopedale, Makkovik, St. Peter's Bay) along $750 \mathrm{~km}$ of the coast. Nest initiation dates (calculated by candling eggs) ranged over a four- to five-week period and were positively associated with latitude: the earliest mean initiation date (5 June) was in St. Peter's Bay in the south and the latest (27 June) at Nain in the north. Mean clutch size ranged from 3.5 to 4.2 and varied by area and year; eiders nesting in Nain had the smallest clutches. In 1999, the highest nest density (49.8 nests/ha) was observed in Nain and the lowest (3.9 nests/ha) in Makkovik. In some cases, we used boat surveys to assess eider presence and absence and found it to be a reliable method; this search technique could be beneficial to researchers working in remote locations where operational costs are high.
\end{abstract}

Key words: common eider, Somateria mollissima, Labrador, nest initiation, nest surveys, clutch size

RÉSUMÉ. On connaît mal le statut, la distribution et l'écologie de nidification de l'eider à duvet (Somateria mollissima) qui se reproduit au Labrador. Cette étude représente un premier pas vers une meilleure compréhension de l'écologie de nidification de l'eider sur la côte du Labrador, une zone de chevauchement entre la sous-espèce du nord (S. m. borealis) et celle américaine ( $S$. m. dresseri) de l'eider à duvet. Durant 1998 et 1999, on a cherché des eiders nicheurs dans 187 îlots à quatre endroits (du nord au sud: Nain, Hopedale, Makkovik, baie de St. Peter's) répartis sur $750 \mathrm{~km}$ de rivage. Les dates du début de la couvaison (calculées en mirant les œufs) s'étalaient sur une période de quatre à cinq semaines et étaient associées positivement à la latitude: c'est dans la baie de St. Peter's dans le sud qu'on a observé la date moyenne du début de la couvaison la plus précoce (5 juin), et à Nain dans le nord, la plus tardive (27 juin). La taille moyenne de la couvée allait de 3,5 à 4,2 et variait selon l'endroit et l'année; les eiders qui nichaient à Nain avaient les plus petites couvées. En 1999, la plus forte densité de nids ( 49,8 nids/ha) a été observée à Nain et la plus faible (3,9 nids/ha), à Makkovik. Dans certains cas, on a utilisé des relevés effectués à partir d'embarcations pour établir la présence et l'absence d'eiders, méthode qui s'est avérée fiable; cette technique de recherche pourrait être bénéfique aux chercheurs travaillant dans des lieux éloignés où les coûts d'opération sont élevés.

Mots clés: eider à duvet; Somateria mollissima, Labrador, début de la couvaison, relevés des nids, taille de la couvée

Traduit pour la revue Arctic par Nésida Loyer.

\section{INTRODUCTION}

Common eiders (Somateria mollissima) are large sea ducks with a circumpolar breeding distribution (Circumpolar Seabird Working Group, 1997). They are differentiated into seven subspecies, four of which occur in North America. These subspecies show substantial variation in body size, clutch size, timing of nesting, nesting density, migratory tendencies, and other aspects of their breeding ecology (Goudie et al., 2000; Robertson et al., 2001). Two subspecies breed along the Labrador coast: S. m. borealis and $S$. $m$. dresseri. The point of demarcation between the two is generally considered to be Groswater Bay (Mendall,
1980; Goudie et al., 2000), with the range of dresseri extending southward and that of borealis northward. However, there is undoubtedly an area of overlap, and individuals showing morphometric features that are intermediate between the two subspecies (intergrades) are known to be common along the southern half of the Labrador coast (Mendall, 1980, 1986).

Very little is known about the current size of eider populations along the Labrador coast, the degree of intermixture of the two subspecies, or their population trends and nesting ecology. The goal of this paper is to document aspects of the nesting ecology of common eiders breeding at four sites along the Labrador coast. Specifically, we document clutch

\footnotetext{
${ }^{1}$ Labrador Inuit Association, Box 382 Station "C," Goose Bay, Labrador, Newfoundland and Labrador A0P 1C0, Canada; kchaulk@nunatsiavut.com

${ }^{2}$ Canadian Wildlife Service, 6 Bruce Street, Mount Pearl, Newfoundland, Newfoundland and Labrador A1N 4T3, Canada

${ }^{3}$ Department of Psychology, Memorial University of Newfoundland, St. John's, Newfoundland, Newfoundland and Labrador A1B 3X9, Canada
}

(C) The Arctic Institute of North America 


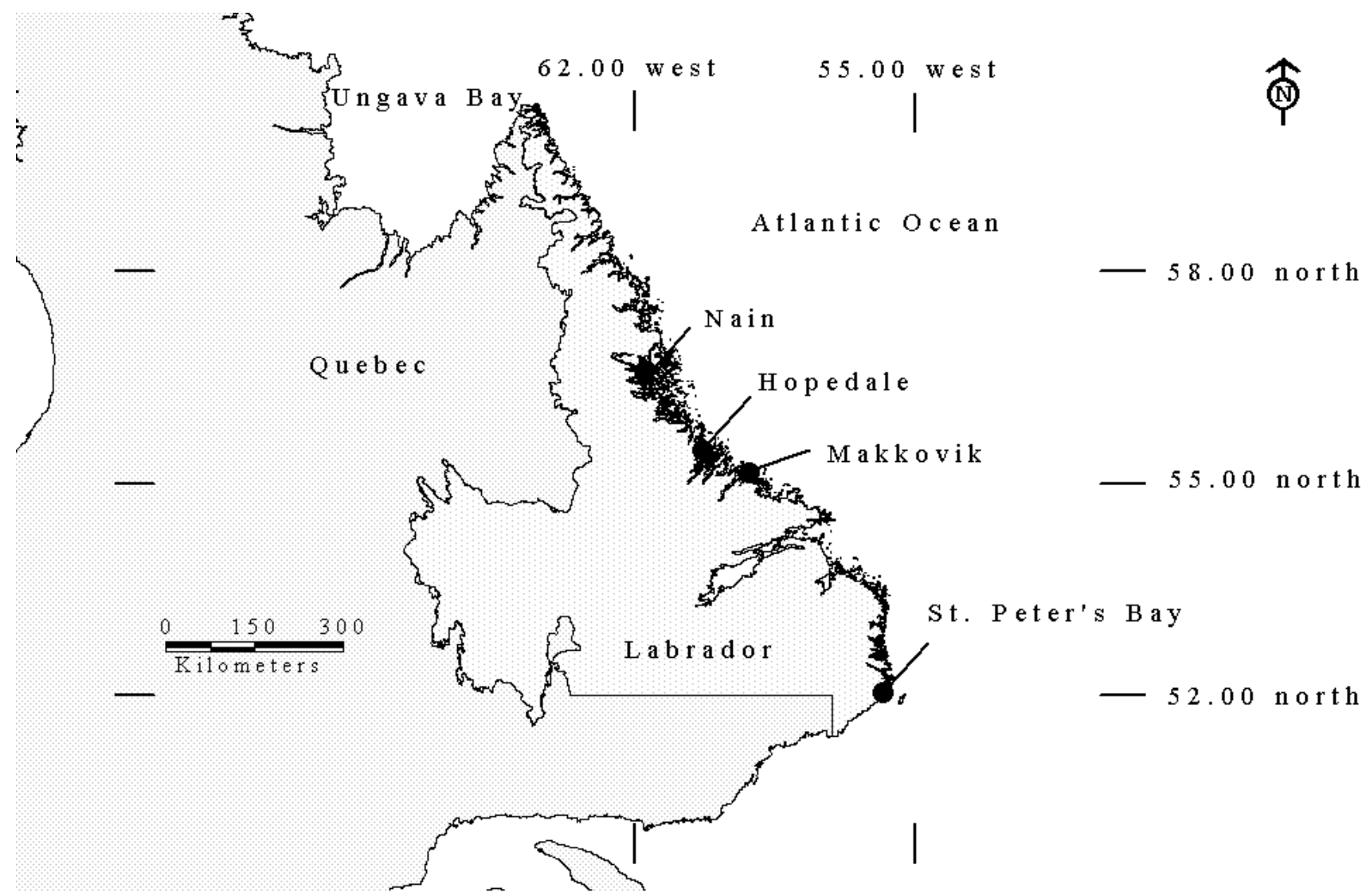

FIG. 1. Map of the Labrador coast, showing study area. Black dots show general location of communities adjacent to the four areas surveyed in 1998 and 1999.

size, timing of nesting, and nesting density at these four sites and compare these values with those documented for eiders nesting in other parts of North America.

\section{STUDY AREA}

Archipelagos near the communities of Nain and Hopedale were surveyed during 1998 and 1999; in 1999, archipelagos near the community of Makkovik and in St. Peter's Bay were also surveyed (Fig. 1). The archipelagos adjacent to Nain, Hopedale, and Makkovik were selected for study because they occur inside the Labrador Inuit Association (LIA) land-claim area, and baseline data were anticipated to form the basis of natural resource co-management between the LIA and the Canadian Wildlife Service (CWS). St. Peter's Bay was added after community groups requested it be assessed for consideration as a protected area for migratory birds.

The Nain study area (ca. $3383 \mathrm{~km}^{2}$ ) contained 1000 islands ranging in size from 0.01 to $44800 \mathrm{ha}$. The Hopedale study area (ca. $566 \mathrm{~km}^{2}$ ) contained 650 islands ranging in size from 0.01 to 3875 ha. The Makkovik study area (ca. $763 \mathrm{~km}^{2}$ ) contained 300 islands ranging in size from 0.01 to 3396 ha. The St. Peter's Bay study area was much smaller (ca. $13 \mathrm{~km}^{2}$ ), containing 20 islands ranging in size from 0.03 to 23.43 ha (Table 1 ).
All regions shared similar environmental characteristics, such as a northern maritime climate and vegetation composed primarily of moss, lichen, forbs, grass, and sedge. The archipelagos of Nain, Hopedale, and Makkovik typically comprised barren islands with sparse vegetation and very limited nesting cover. Islands in St. Peter's Bay had more ground vegetation and woody cover, such as stunted black spruce (Picea mariana). All four archipelagos are classified as coastal barrens (Lopoukhine et al., 1978). They are considered to have a high-boreal ecoclimate (Meades, 1990) and a Low Arctic oceanographic regime (Nettleship and Evans, 1985).

\section{METHODS}

In all areas, islands were selected for study by random sampling or field selection (Table 2). Field selection of islands was the only method used in 1998, and it was based on a haphazard selection method. However, we limited our searches to islands that were estimated to be smaller than 30 ha. On the first day of surveys for a community, we evaluated weather conditions in order to choose a general direction of travel. Using direction of travel, we chose an island cluster for sampling from an overview of the 1:50000 National Topographic Series (NTS) map sheets for the general area. After the first island cluster was 
TABLE 1. Summary of study area extent, island count, total island area, and island size.

\begin{tabular}{|c|c|c|c|c|c|}
\hline Study Area & Nain & Hopedale & Makkovik & St. Peter's Bay & Total \\
\hline Extent $\left(\mathrm{km}^{2}\right)$ & 3383 & 566 & 763 & 13 & 4725 \\
\hline Number of Islands & 1000 & 650 & 300 & 20 & 1970 \\
\hline Islands $/ \mathrm{km}^{2}$ & 0.29 & 1.15 & 0.39 & 1.54 & 0.42 \\
\hline Mean Island Size (ha) & 113.3 & 22.0 & 27.6 & 3.2 & 41.5 \\
\hline SD Island Size (ha) & 1602.7 & 205.3 & 219.5 & 5.7 & 748.2 \\
\hline
\end{tabular}

surveyed, we chose additional islands for sampling on the basis of further evaluation of the NTS map sheets and an assessment of transit time. Our goal was to maximize the spatial sampling distribution while balancing logistical constraints such as weather, travel distances, and time. All islands were selected for survey before the study team could visually assess islands for productivity or accessibility. On subsequent days, a new direction and island cluster were chosen and the method repeated. Randomly selected islands were chosen by assigning serial numbers to all islands less than 30 ha on 1:50000 topographic map sheets. Repeat surveys of Hopedale and Nain in 1999 were conducted by randomly sampling islands selected in 1998 .

Islands were accessed by powerboat and were surveyed from the water at distances of up to $10 \mathrm{~m}$ from shore for the presence or absence of nesting eiders. Only small islands (i.e., $<1$ ha) were searched in this manner. The study team assumed nesting eiders were absent if they did not flush from the island (Nakashima and Murray, 1988; Robertson and Gilchrist, 1998; Merkel, 2004). In 1999, newly selected islands were surveyed first from a boat and classed as "eiders present" or "eiders absent." To assess the accuracy of boat-based absence classification, we also conducted ground surveys for 30 islands classed as "eiders absent." Islands that were searched by boat only were classed as "boat-searched."

Ground surveys were conducted using standard search methods employed by CWS (Nettleship, 1976) and other researchers (Falardeau et al., 2003; Merkel, 2004): two to four people walked over the islands searching for signs of eider nesting. In the three northern archipelagos, islands were for the most part barren with limited cover, so that hens and unattended nests were easily detected. Several islands, where nest searches were halted because of weather or logistical considerations, were classed as "partially searched." Partially searched and boat-searched islands were not used in calculating the mean number of nests per island.

During the two study years, 187 different islands were searched: 113 islands in 1998 and 141 islands in 1999 (Table 2). Of these, 25 islands from Nain and 42 islands from Hopedale were surveyed in both years (Table 2). In 1998, Hopedale was surveyed from 30 June to 4 July, followed by Nain from 6 to 10 July. In 1999, St. Peter's Bay was surveyed first, on 22 and 23 June; followed by Makkovik, from 25 June to 3 July; Hopedale, from 4 to 12 July; and finally Nain, from 13 to 15 July.

For each common eider nest observed, information was recorded on apparent clutch size, nest age, and nest status (incubating, hatching, hatched, depredated, or unknown). Nest status classes were defined as follows: incubatingcurrent season nest containing eggs; hatching-at least one chick was breaking its shell; hatched-at least one chick was completely out of its shell; depredated—broken and bloody eggs were present within or immediately adjacent to the nest; and unknown-nest was in disrepair, with no eggs or signs of depredation (K. Chaulk, unpubl. data). Primary predators for these eiders were large gulls (Goudie et al., 2000), and occasionally evidence of mammalian predation was found. It was assumed that mammals were able to access the islands using landfast ice, ice bridges, and floating ice pans.

Nest initiation dates were estimated by candling incubating nests (Weller, 1956) and assuming an incubation period of 24 to 26 days for hatching nests (Goudie et al., 2000). The initiation date was determined by adding the number of eggs in the nest minus one to the age of the egg, assuming a laying rate of one egg per day and incubation starting after the second or third egg (Goudie et al., 2000), and subtracting this number from the survey date. Apparent clutch sizes were calculated using only nests classified as incubating. Nests with more than six eggs were not aged: such nests are generally considered dump nests produced by two or more females (Swennen, 1983; Robertson, 1995) and were therefore omitted from the analysis. Calculation of island nest counts and nest density was based on islands that were completely searched. Island sizes were based on GIS analysis of digital 1:50 000 maps for the coast of Labrador. Geodetic coordinates are reported as Latitude and Longitude, decimal degrees, North American Datum 1983. Nest initiation, nest counts, nest density, and clutch size data collected in 1999 were analyzed using one-way ANOVA with community as the only factor in the model, and critical alpha was set at 0.05 for all tests.

\section{RESULTS}

In 1998, 113 islands were searched and 720 eider nests were counted. Overall, there were 6.6 nests/island or 14.3 nests/ha (Table 3). In 1999, 141 islands were searched and 1439 eider nests were counted. On average there were 12.6 nests/island or 18.0 nests/ha (Table 3). Makkovik had the lowest percentage of islands with eiders present, followed by Hopedale, Nain, and St. Peter's Bay (Table 2).

Islands in Nain and Hopedale that were surveyed in both 1998 and 1999 were analyzed for differences in nest 
TABLE 2. Summary of island sampling method, search status, and island size by survey area during 1998 and 1999.

\begin{tabular}{|c|c|c|c|c|c|c|c|c|c|}
\hline & \multicolumn{2}{|c|}{ Nain } & \multicolumn{2}{|c|}{ Hopedale } & \multirow{2}{*}{$\frac{\text { Makkovik }}{1999}$} & \multirow{2}{*}{$\begin{array}{c}\text { St. Peter's Bay } \\
1999\end{array}$} & \multicolumn{3}{|c|}{ Total } \\
\hline & 1998 & 1999 & 1998 & 1999 & & & 1998 & 1999 & All \\
\hline \multicolumn{10}{|l|}{ Sampling Method } \\
\hline Field Selection & 43 & 5 & 70 & 6 & 22 & 10 & 113 & 43 & 156 \\
\hline Random & 0 & 10 & 0 & 0 & 21 & 0 & 0 & 31 & 31 \\
\hline Repeated Survey & 0 & 25 & 0 & 42 & 0 & 0 & 0 & 67 & 67 \\
\hline Total & 43 & 40 & 70 & 48 & 43 & 10 & 113 & 141 & 254 \\
\hline \multicolumn{10}{|l|}{ Search Status } \\
\hline Complete & 43 & 31 & 66 & 46 & 27 & 10 & 109 & 114 & 223 \\
\hline Partial & 0 & 1 & 4 & 0 & 2 & 0 & 4 & 3 & 7 \\
\hline Boat & 0 & 8 & 0 & 2 & 14 & 0 & 0 & 24 & 24 \\
\hline Total & 43 & 40 & 70 & 48 & 43 & 10 & 113 & 141 & 254 \\
\hline \multicolumn{10}{|l|}{ Island Size (ha) ${ }^{1}$} \\
\hline Total Area & 81.4 & 34.1 & 188.2 & 140.5 & 73.4 & 56.8 & 269.6 & 304.8 & 574.4 \\
\hline Mean & 1.9 & 1.1 & 2.9 & 3.0 & 2.7 & 5.7 & 2.5 & 2.7 & 2.6 \\
\hline $\mathrm{SD}$ & 2.4 & 1.1 & 6.5 & 7.2 & 3.2 & 7.1 & 5.3 & 5.4 & 5.4 \\
\hline Min & 0.04 & 0.07 & 0.07 & 0.07 & 0.15 & 0.39 & 0.04 & 0.07 & 0.04 \\
\hline Max & 12.1 & 4.9 & 46.1 & 46.1 & 13.4 & 23.4 & 46.1 & 46.1 & 46.1 \\
\hline $\mathrm{N}$ & 43 & 31 & 66 & 46 & 27 & 10 & 109 & 114 & 223 \\
\hline Islands with Eiders (\%) & 74 & 60 & 50 & 60 & 34 & 80 & 59 & 54 & 57 \\
\hline
\end{tabular}

${ }^{1}$ Based on islands that were completely searched.

counts using the General Linear Model. For islands searched in 1999, the number of nests per island differed significantly between areas $(\mathrm{F}=14.45 ; \mathrm{df}=3,110 ; p<0.01)$, with the highest nest counts in St. Peter's Bay followed by Nain, Hopedale, and Makkovik (Table 3). Nest density in 1999 also varied by region $(\mathrm{F}=3.44 ; \mathrm{df}=3,110 ; p=0.02)$. The highest nest densities were observed in Nain, followed by St. Peter's Bay, Hopedale, and Makkovik (Table 3).

In $1998,7.5 \%$ of the nests found were depredated, while in 1999 , only $3.3 \%$ of nests were depredated (Table 3 ). The highest level of hatched and hatching nests was observed in 1999 in St. Peter's Bay followed by Hopedale. Nest initiation date varied by region in $1999(\mathrm{~F}=95.97 ; \mathrm{df}=3,154 ; p<0.01)$, occurring earliest in St. Peter's Bay in the south, followed by Makkovik, Hopedale, and Nain (Table 3). Mean nest initiation date for Hopedale and Nain was approximately the same in both 1998 and 1999. Clutch size varied by region in 1999 $(\mathrm{F}=3.25 ; \mathrm{df}=3,944 ; p=0.02)$, with the smallest clutch size occurring in Nain and the largest in Hopedale (Table 3). In 1999, islands were assessed by boat and classed as eiders absent. Then 30 of these islands were surveyed on foot to verify the classification made by boat, and all 30 were confirmed as eiders absent.

\section{DISCUSSION}

According to accounts by local residents during the 1998 and 1999 surveys, the timing of spring breakup, the subsequent transition, and onset of spring and summer were typical for all study areas. Overall, our surveys appeared to be well timed, as most nests were incubating ( $\geq 80 \%$ for 4 of 6 survey areas; Table 1) except at St. Peter's Bay and Hopedale in 1999, when we observed a higher percentage of hatched nests.
Our method of assessing small islands by boat to see if eiders were present and classifying them as unoccupied if none flushed has been used before (Nakashima and Murray, 1988; Robertson and Gilchrist, 1998; Merkel, 2004). Avoiding landings on islands that do not have nesting birds can significantly speed up survey times and reduce survey effort. However, this technique had yet to be verified. In this study, 30 islands classified as unoccupied by boat surveys were subsequently assessed on foot, and in all cases no eider nests were found. We do caution other researchers, however, and suggest that they employ a similar verification technique for individual study areas. We also suggest not using this boat survey method when investigating larger islands.

St. Peter's Bay in southern Labrador had the earliest average nest initiation date (5 June) of any area surveyed. In Labrador, nest initiation date was positively associated with latitude, and is likely related to the timing of spring ice breakup (Goudie et al., 2000). Another factor that might influence nest initiation is subspecies affiliation. We found that nest dates were similar during 1998 and 1999 in both Hopedale and Nain, occurring in mid to late June. Eiders nesting in Labrador showed relatively late nest initiation dates and subsequent hatching dates compared to some eider populations. Peak nest initiation for S. $m$. dresseri nesting in the St. Lawrence estuary occurred during the third week of May (van Dijk, 1986) and for S. $m$. sedentaria populations breeding in western Hudson Bay, at a latitude similar to Labrador's, peak nest initiation was in late May (Robertson, 1995). Our results are more comparable to those for $S$. $m$. borealis populations, such as those nesting in southern Baffin Island (Cooch, 1965), Devon Island (Prach et al., 1986), and Ungava Bay (Falardeau et al., 2003), or S. m. sedentaria populations breeding in eastern Hudson Bay (Freeman, 1970), all of 
TABLE 3. Summary of nest counts, nest density, nest status, nest initiation, and clutch size, by survey area and year.

\begin{tabular}{|c|c|c|c|c|c|c|c|c|c|}
\hline & \multicolumn{2}{|c|}{ Nain } & \multicolumn{2}{|c|}{ Hopedale } & \multirow{2}{*}{$\frac{\text { Makkovik }}{1999}$} & \multirow{2}{*}{$\frac{\text { St. Peter's Bay }}{1999}$} & \multicolumn{3}{|c|}{ Total } \\
\hline & 1998 & 1999 & 1998 & 1999 & & & 1998 & 1999 & All \\
\hline \multicolumn{10}{|l|}{ Nest Count/Island } \\
\hline Mean & 12.3 & 20.3 & 2.9 & 4.3 & 4.0 & 50.6 & 6.6 & 12.6 & 9.9 \\
\hline $\mathrm{SD}$ & 18.1 & 26.2 & 6.6 & 7.7 & 9.9 & 56.3 & 13.2 & 25.9 & 26.1 \\
\hline N (completely searched) & 43 & 31 & 66 & 46 & 27 & 10 & 109 & 114 & 223 \\
\hline \multicolumn{10}{|l|}{ Nest Density (nests/ha) } \\
\hline Mean & 29.8 & 49.8 & 4.2 & 5.1 & 3.9 & 17.3 & 14.3 & 18.0 & 16.2 \\
\hline SD & 105.2 & 124.0 & 9.7 & 10.9 & 10.4 & 18.0 & 67.2 & 67.6 & 67.6 \\
\hline N (completely searched) & 43 & 31 & 66 & 46 & 27 & 10 & 109 & 114 & 223 \\
\hline \multicolumn{10}{|l|}{ Nest Status (\%) } \\
\hline Incubating & 80.3 & 79.8 & 87.3 & 65.8 & 91.5 & 43.3 & 82.2 & 65.9 & 71.3 \\
\hline Hatched & 1.3 & 0.8 & 1.1 & 5.5 & 0.0 & 31.0 & 1.3 & 12.0 & 8.4 \\
\hline Hatching & 0.2 & 1.1 & 0.0 & 4.5 & 0.0 & 4.3 & 0.1 & 2.6 & 2.0 \\
\hline Depredated & 8.1 & 3.0 & 5.8 & 7.0 & 0.0 & 3.4 & 7.5 & 3.5 & 4.8 \\
\hline Unknown & 10.2 & 15.3 & 5.3 & 17.1 & 8.5 & 18.0 & 8.9 & 16.0 & 13.5 \\
\hline $\mathrm{N}$ (count) & 532 & 628 & 189 & 199 & 106 & 506 & 720 & 1439 & 2159 \\
\hline \multicolumn{10}{|l|}{ Nest Initiation } \\
\hline Mean (date) & $27 / 06$ & $28 / 06$ & $20 / 06$ & $20 / 06$ & $18 / 06$ & $5 / 06$ & $24 / 06$ & $18 / 06$ & $20 / 06$ \\
\hline SD (days) & 5.0 & 6.1 & 5.4 & 6.6 & 6.5 & 7.0 & 6.3 & 11.0 & 14.2 \\
\hline $\mathrm{N}$ & 217 & 52 & 142 & 46 & 19 & 41 & 359 & 158 & 517 \\
\hline \multicolumn{10}{|l|}{ Clutch Size } \\
\hline Mean & 3.7 & 3.7 & 4.4 & 4.0 & 3.9 & 3.8 & 3.9 & 3.8 & 3.8 \\
\hline SD & 1.5 & 1.4 & 1.4 & 1.2 & 1.3 & 1.1 & 1.5 & 1.3 & 1.4 \\
\hline $\mathrm{N}$ & 427 & 501 & 165 & 131 & 97 & 219 & 592 & 948 & 1540 \\
\hline
\end{tabular}

which show peak nest initiation dates ranging from midJune to early July.

Clutch size showed statistically significant differences among regions in 1999. The largest average clutch size was observed in Hopedale, and the smallest in Nain. Mean clutch sizes for $S$. m. borealis vary from 3.3 to $3.6 \mathrm{eggs}$ (summarized in Robertson et al., 2001), although Falardeau et al. (2003), who observed $S$. m. borealis nesting in Ungava Bay in 2000, reported clutch sizes as low as 2.0 to 2.9 eggs per nest. Mean clutch sizes for $S . m$. dresseri vary from 3.6 to 4.4 , while $S$. m. sedentaria show larger clutch sizes ranging from 4.0 to 4.4 eggs (Robertson et al., 2001). The clutch sizes we observed in Labrador were generally higher than the usual range for $S$. $m$. borealis, but within the range normally seen for $S$. $m$. dresseri.

Nest densities were highly variable among regions, with some regions showing dispersed nesting, and others, such as Nain, showing relatively dense breeding. Makkovik had the lowest ratio of eiders present on islands and the lowest nest densities. It is unclear why this pattern arose, as island nest density and archipelago island density did not appear to be related. Nest densities are also highly variable in the different subspecies. For $S$. $m$. dresseri, nest densities in the Gulf of St. Lawrence averaged 3 nests/ha, while colonies in the estuary reached 741.5 nests/ha (Chapdelaine et al., 1986). S. m. borealis typically exhibits low nesting densities (Goudie et al., 2000). S. m. sedentaria populations showed nest densities similar to or slightly lower than those of Labrador breeders, ranging from 1.0 15.9 nests per island (Nakashima and Murray, 1988; Robertson and Gilchrist, 1998). Nesting densities in all common eider subspecies are likely to be related to a variety of interacting local factors, including, but not limited to, available nesting islands and brood-rearing areas, predator numbers, and population density.

Common eiders breeding along the Labrador coast show some traits similar to those of $S$. $m$. borealis, such as late nest initiation, but also show large clutch sizes, which are more typical of S. m. dresseri (Robertson et al., 2001). However, characteristics such as nest initiation could also vary because of environmental factors, such as timing of spring breakup. Since Labrador eiders have been shown to be intergrades between two subspecies (Mendall, 1980, 1986) and show intermediate nesting ecology, we suggest that for management purposes they be considered separately from other populations. Future research on common eiders in Labrador should include the development of population trends, the study of population genetics, identification of wintering areas, and an assessment of biophysical factors that influence breeding distribution and abundance.

\section{ACKNOWLEDGEMENTS}

Special thanks to B. Turner (Canadian Wildlife Service); N. Anderson, E. Anderson, C. Bradley, K. Dicker, C. Dyson, and C. Poole (Fisheries and Oceans Canada); J. Rowell, B. Anderson, W. Hunter, and E. Merkuratsuk (Labrador Inuit Association); and T. Broomfield and E. Pottle. Special thanks go to Cheryl Hope for help in editing the manuscript and to Shawn Broomfield for help in preparing the data for analysis. The Labrador Inuit Association, the Canadian Wildlife Service, the Northern Ecosystem Initiative, and INCO provided funding for this study. We also thank Austin Reed, 
Lynn Noel, and Karen McCullough for their helpful review of our manuscript.

\section{REFERENCES}

CHAPDELAINE, G., DUPUIS, P., and REED, A. 1986. Distribution, abondance et fluctuations des populations d'eider à duvet dans l' estuaire et le golfe du Saint-Laurent. In: Reed, A., ed. Eider ducks in Canada. Occasional Report Series No. 47. Ottawa: Canadian Wildlife Service. 6-11.

CIRCUMPOLAR SEABIRD WORKING GROUP. 1997. Circumpolar eider conservation strategy and action plan. Akureyri, Iceland: Conservation of Arctic Flora and Fauna. $16 \mathrm{p}$.

COOCH, F.G. 1965. The breeding biology and management of the northern eider (Somateria mollissima borealis), Cape Dorset, NWT. Wildlife Management Bulletin Series 2, No. 10. Ottawa: Canadian Wildlife Service.

FALARDEAU, G., RAIL, J.-F., GILLILAND, S., and SAVARD, J.-P.L. 2003. Breeding survey of common eiders along the west coast of Ungava Bay, in summer 2000, and a supplement on other nesting aquatic birds. Technical Report Series No. 405. Sainte-Foy, Quebec: Canadian Wildlife Service. 67 p.

FREEMAN, M.M.R. 1970. Observations of the seasonal behaviour of the Hudson Bay eider (Somateria mollissima sedentaria). Canadian Field-Naturalist 84:145-153.

GOUDIE, R.I., ROBERTSON, G.J., and REED, A. 2000. Common eider (Somateria mollissima). In: Poole, A., and Gill, F., eds. The birds of North America, No. 546. Philadelphia, Pennsylvania: The Birds of North America, Inc.

LOPOUKHINE, N., PROUT, N.A., and HIRVONEN, H.E. 1978. The ecological land classification of Labrador: A reconnaissance. Ecological Land Classification Series 4. Halifax, Nova Scotia: Lands Directorate, Environmental Management Service, Fisheries and Oceans Canada and Environment Canada. 85 p.

MEADES, S. 1990. Natural Regions of Newfoundland and Labrador. Report prepared for the Protected Areas Association of Newfoundland and Labrador. Available from Parks and Natural Areas Division, Provincial Department of Environment and Conservation, 33 Reid's Lane, Deer Lake, NL A8A 2A3. 337 p.
MENDALL, H.L. 1980. Intergradation of eastern North American common eiders. Canadian Field-Naturalist 94:286-292.

1986. Identification of eastern races of common eider. In: Reed, A., ed. Eider ducks in Canada. Occasional Report Series No. 47. Ottawa: Canadian Wildlife Service. 82-88.

MERKEL, F.R. 2004. Evidence of population decline in common eiders breeding in Western Greenland. Arctic 57(1):27-36.

NAKASHIMA, D.J., and MURRAY, D.J. 1988. The common eider (Somateria mollissima sedentaria) of eastern Hudson Bay: A survey of nest colonies and Inuit ecological knowledge. Report No. 102. Ottawa: Environmental Studies Revolving Funds. xxiv +174 p.

NETTLESHIP, D.N. 1976. Census techniques for seabirds of Arctic and eastern Canada. Occasional Paper Number 25. Ottawa: Canadian Wildlife Service. 33 p.

NETTLESHIP, D.N., and EVANS, P.G.H. 1985. Distribution and status of Atlantic Alcidae. In: Nettleship, D.N., and Birkhead, T.R., eds. The Atlantic Alcidae. London: Academic Press. $53-154$.

PRACH, R.W., SMITH, A.R., and DZUBIN, A. 1986. Nesting of the common eider near the Hell Gate-Cardigan Strait polynya, 1980-81. In: Reed, A., ed. Eider ducks in Canada. Occasional Report Series No. 47. Ottawa: Canadian Wildlife Service. 127135.

ROBERTSON, G.J. 1995. Annual variation in common eider egg size: Effects of temperature, clutch size, laying date, and laying sequence. Canadian Journal of Zoology 73:1579-1587.

ROBERTSON, G.J., and GILCHRIST, H.G. 1998. Evidence of population declines among common eiders breeding in the Belcher Islands, Northwest Territories. Arctic 51(4):378-385.

ROBERTSON, G.J., REED, A., and GILCHRIST, H.G. 2001. Clutch, egg and body size variation among common eiders breeding in Hudson Bay, Canada. Polar Research 20:85-94.

SWENNEN, C. 1983. Reproductive output of eiders (Somateria mollissima mollissima) on the southern border of its breeding range. Ardea 71:245-254.

VAN DIJK, B. 1986. The breeding biology of eiders at Île aux Pommes, Québec. In: Reed, A., ed. Eider ducks in Canada. Occasional Report Series No. 47. Ottawa: Canadian Wildlife Service. 119-126.

WELLER, M.W. 1956. A simple field candler for waterfowl eggs. Journal of Wildlife Management 20:111-113. 